\title{
Orchid agonistes
}

\section{The sweet smell of the past.}

\begin{abstract}
Misha Angrist
When the old-timers started dancing, Celeste looked sick to her stomach.

We were at the wedding of a mutual friend, watching the happy-ish couple float and then lurch across the floor, while the band played Hava Nagila as a dirge, the arrangement a tip of the cap to the Charismatics and Orchidae sympathizers among the guests.
\end{abstract}

"Ah, classic rock," I said, surprised by my own nostalgia.

Celeste flashed me wistful black eyes and a rueful smile, the lioness still a force to be reckoned with, even at the end of a long and bitter winter. As the accordion breathed out one last schmaltzy chorus, she leaned into me. "Had I known it would be like this, I'd have worn black."

Left to my own devices, I would never have transcended my station in life. I had neither the wherewithal nor the charm. I would forever be a 'Herb', a 'Lester', a 'Slide Rule. But give me credit: I married well. Celeste plucked me out of an Urban Planning Collective for the state-sponsored Montessori school initiative, intrigued, she liked to say, by the sharpness of my lines and the spotlessness of my drafting table. Her parents were appalled: their daughter, a two-term holism minister, would take up with ... an engineer? No amount of argument from Celeste would assuage them. Engineers were exotic life forms, but what was a Dandelion actually good for?

Celeste was the product of emogenics, the breeding programme to optimize genes and environments for those with heightened sensitivities to external stimuli. She was about as close as anyone had come to the ideal: she was a human nerve-ending in a cotton sundress, although her innate modesty prevented her from ever acknowledging it with anything more than a blush.

For a time things were good in the shade of the Orchids. Poets and playwrights orated (God, they loved to orate), legislated and adjudicated. Synaesthetics, sculptors and acupuncturists ascended, and, with a bit of feng shui, got the trains to run within two standard deviations of on time. The world, it seemed, was developing a more pungent and appetizing fragrance, and deeper contours. People stopped inquiring of one another, "How are you?" and instead asked, "How are you?" On any given day the skies were dotted with images of Dalís elephants and obelisks, and even the teeming

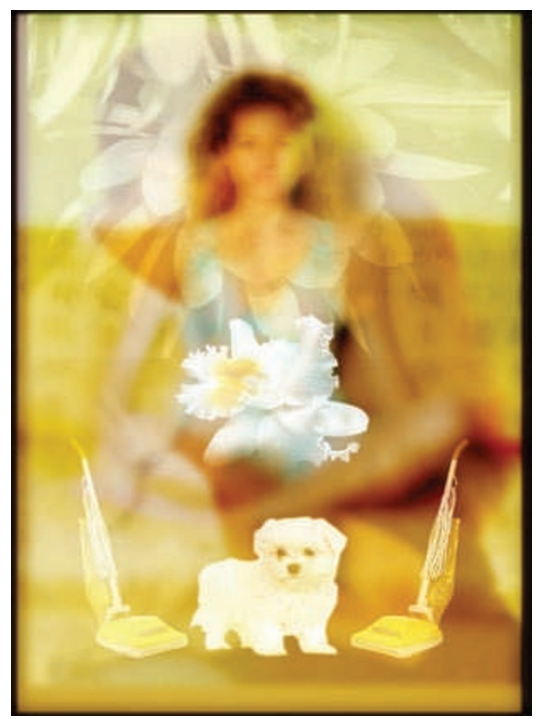

cities echoed with the felicitous, seductive caws of languid flocks of lavender doves.

If the Orchids and the rest of the aesthetocracy had their serotonin properly calibrated, they could move mountains simply by uncurling their toes. No problem was intractable. When the salt mines collapsed, tears - of which there were plenty - were bottled. Miraculin proteins became a staple - suddenly Brussels sprouts tasted of brown sugar and kale of honeysuckle. The median body-mass index fell to 22 and hunger declined. Even Herbs and Lesters became objects of desire, although they were unprepared for and mystified by this.

Lord knows I was. It seemed as though a sultry friendliness and the vibration of Eros could be found just about everywhere. Many of the Dandies didn't want to be left out, so they played along. But I often felt confused. Celeste acted as though my inability to live in the moment was charming. My sister (an engineer, natch) thought Celeste was patronizing me.

It couldn't last. Caffeine trafficking returned; gangs of kids were spotted with calculators, blinding yellow highlighters and dog-eared physics textbooks. Desperate parents put aluminium foil on their windows and stockpiled Ritalin. When the Orchids tried to pull back, they couldn't: their senses were congenitally, deterministically acute. And there was no chemical remedy, either: someone had tainted the Strategic Antidepressant Reserve with Cialis.

The Orchids were in freefall, battle lines forming around them. From their mountain retreats, renegade bands of Tough Love Therapists began circulating 'neurosamizdat': pamphlets touting ordinariness and laced with modafinil. Twelve-step programmes were eclipsed by 13-, 17- and, eventually, 174-step programmes. Graffiti and bumper stickers appeared: "No Chemo for the Emo", "Spray the Orchids" and "Bring The Mean". In grocery store parking lots the Flaxseed of God took up arms against the self-described "Crème Brulée-ers".

As things spiralled downwards, Celeste lost her bearings, a wounded petal. She went days without sleep, only to collapse in the hot springs or on her parapet in midsentence. While her staff kept up a front, she retreated from public view ... and from mine. In a near-stupor, one night she gathered a few clothes and the puppy from the bungalow. I didn't see her for weeks, but friends told me she'd begun a passionate affair with a centenarian Leonard Cohen, who was still the nominal minister of finance, his fedora, gravelly basso profundo and nylon-string guitar a fixture on C-SPAN. Clearly she needed something that I was unable to give.

I was never a Heartless Dandy; I never stopped loving her. I remembered her crosslegged on the goatskin rug beneath the skylight, the sun throwing shadows across her face, transcendent, while I ran the vacuum cleaner around her. "This is as alive as I've ever felt!" she said above the din, palms up, eyes closed. "Me too!" I shouted.

When I saw her at the wedding, alone and vulnerable, it rattled me. I had just been offered a cushy job with the Esprit de Corps of Engineers, a quasi-governmental programme whose charge was to develop infrastructure that would consume more petroleum. It was a nice, safe gig. I had been feeling pretty good about myself.

But Celeste undid me. I had absorbed too much of her. Seeing her stirred something, even in someone whose dopamine receptors had long since atrophied from disuse. When she leaned into me and spoke about wearing black, I turned around and folded her into my arms. I closed my eyes; the smell of fresh-baked bread was in my nose and a field of poppies appeared before me.

When I opened my eyes, the band was packing up and the guests were drifting towards the exits. Celeste exhaled, her passion giving way to resignation, and started to pull away, but I stopped her.

"First," I said, "we must dance."

Misha Angrist is at the Duke Institute for Genome Sciences and Policy. His book Here is a Human Being: At the Dawn of Personal Genomics comes out this autumn. 